\title{
The Evolution of Depleted Uranium as an Environmental Risk Factor: Lessons from Other Metals
}

\author{
Wayne E. Briner* \\ Department of Psychology, University of Nebraska at Kearney, Kearney, NE 68849, USA \\ *Correspondence to Dr. Wayne E. Briner, Email: brinerw@unk.edu
}

Received: 04 November 2005 / Accepted: 31 May 2006 / Published: 30 June 2006

\begin{abstract}
Depleted uranium (DU) is used in both civilian and military applications. Civilian uses are primarily limited to ballast and counterweights in ships and aircraft with limited risk of environmental release. The very nature of the military use of DU releases DU into the environment. DU released into the environment from military use takes the form of large fragments that are chemically unchanged and dust in the form of oxides. DU dust is nearly insoluble, respirable and shows little mobility in the soil. Exposure to DU occurs primarily from inhalation of dust and possible hand to mouth activity. Toxicity of DU is believed to be primarily chemical in nature with radiological activity being a lesser problem. DU has been shown to have a variety of behavioral and neurological effects in experimental animals. DU has been used the Balkans, Afghanistan, and both Iraq wars and there is a high probability of its use in future conflicts. Further, other nations are developing DU weaponry; some of these nations may use DU with a greater radiological risk than those currently in use. The toxicity of DU has been studied mostly as an issue of the health of military personnel. However, many tons of DU have been left in the former theater of war and indigenous populations continue to be exposed to DU, primarily in the form of dust. Little epidemiological data exists concerning the impact of DU on these groups. It may be possible to extrapolate what the effects of DU may be on indigenous groups by examining the data on similar metals. DU has many similarities to lead in its route of exposure, chemistry, metabolic fate, target organs, and effect of experimental animals. Studies should be conducted on indigenous groups using lead as a model when ascertaining if DU has an adverse effect.
\end{abstract}

Keywords: Depleted uranium, Lead, Environmental contamination, Military activity.

\section{Introduction}

\section{Origins of Depleted Uranium}

Depleted uranium (DU) is a byproduct of nuclear fuel processing. DU is depleted, when compared to native uranium, in that a substantial portion of the U-235 isotope has been removed leaving $99.75 \% \mathrm{U}-238$ in the remaining material. DU is $40 \%$ less radioactive than the parent element. DU is extraordinarily dense and pyrophoric making it useful in special applications.

DU is used in some civilian applications, in particular weights and counter weights in ships and aircraft as well as radiation shielding. However, much DU has found its way into military applications where the high density of DU, combined with its pyrophoric properties, make it an excellent material for kinetic based armor piercing weapons. When fired with sufficient velocity DU munitions penetrate conventional armor, enter the interior of the vehicle and combusts.
This process produces a wide variety of DU and other metal fragments.

Combustion of DU produces a variety of uranium oxides in particulate form. When DU is used as a kinetic energy penetrator the explosive impact and combustion of DU produces a cloud containing fine DU particulates. The DU particles in the cloud average 2 microns in size, sufficiently small to enter the pulmonary system and lodge in the alveoli and solublize, with DU entering the bloodstream for an extended period [1]. Once DU has entered the alveoli it may have a pulmonary half-life of nearly 4 years [2]. Exposure to DU may continue after the end of combat operations because DU has little mobility in the soil allowing it to continue to be an exposure risk via inhaled or ingested dust $[3,4]$. DU exposure by inhalation is receiving attention as the most likely route of exposure. Secondary routes of exposure to DU may occur when handling the weapons or armor, if struck by DU containing shrapnel, and exposure of the skin to DU dust or by oral ingestion of DU containing 
soil, dust or water. DU is primarily an alpha and beta particle emitter and its overall low radioactivity skin exposure of external regions of the body are of little concern. However, inhalation or ingestion of DU would allow direct exposure to DU's low-level radioactivity as well as direct chemical activity in the body. Direct chemical activity of DU may be more of a concern than DU's radioactivity [5 - 7]. It is likely that soldiers would be exposed chiefly by secondary routes, while civilian populations that inhabit former combat areas risk exposure by way in inhalation and ingestion of dust, as well as encountering remaining DU fragments. Exposure of soldiers to DU would be limited to fairly discreet amounts of time, while civilian exposure may occur for an indefinite period of time.

\section{Current Populations at Risk of Exposure}

DU munitions have been used in the first Iraq war, the Balkans conflict, the Afghanistan war and the second Iraq war. It has been estimated that 371 tons of DU were deposited in Iraq soils during Desert Storm [8] and an estimated 13 tons deposited in the region of Kosovo [9]. There are estimates that 176 tons of DU was used in the 2003 Iraq War [10]. There are no reliable estimates of the amount used in the Afghanistan war. Estimates of the amount of DU recovered by the militaries are currently unavailable. Presumably any amount remaining after the recovery of large fragments is still in the local environs. The impact of DU on the local inhabitants of former combat zones has been the object of media attention and some anecdotal reports. However, formal studies of local populations are limited to few reports [11 - 20]. These populations have not only suffered DU exposure but have also experienced many of the economic, environmental, physical, social, and emotional deprivations of war, confounding these reports. A lack of understanding of what the effects of long-term exposure to DU also limits these studies. Much of the public concern has focused on cancer rates being linked to DU, however, reproductive outcomes and other organ system effects may be more probable, but may go undetected if not deliberately studied. An additional factor to be considered is the geographic distribution of DU. DU munitions were used in particular locations producing higher concentrations in these areas and perhaps areas downwind from the combat zone. Other regions may be free of DU contamination. Potential health effects are likely to be dependent on the local concentration of DU. Except for one set for the Kosovo region [21] any maps that might exist that describe the distribution of DU do not appear to be available to the public. Lack of knowledge about regional concentrations of DU make the search for potential effects less effective.

\section{Current Understanding of Human Health Effects}

Much of our knowledge of the human effects of DU comes from studies examining Gulf War veterans exposed to DU. Scientific studies directly addressing the health effects of DU on humans are few. Such studies that have been done use only soldiers; consequently, they are limited by the small sample sizes and also the heterogeneous nature of the study groups. Available studies on Gulf War veterans have found elevated DU levels in urine linked to embedded DU fragments [22]. DU urinary excretion has also been linked to high serum prolactin levels and neurocognitive performance [23]. Chromosomal aberrations in lymphocytes of DU exposed veterans have also been found [24]. Other studies examining the effects of DU in veterans have examined the role it might play in Gulf War Illness and are confounded by a number of variables that obscure the effect of DU. This problem is likely to be repeated in any population studied for the effects of DU.

The toxicity of native uranium has been described in the clinical literature. It is well accepted that the target organ of uranium toxicity is the kidney and the skeleton is the main reservoir for this metal. Lung cancer has been described in uranium miners; however, it is unclear if this is due strictly to the effects of uranium of to co-exposure to radon gas. It is likely that the manner and magnitude of exposure to DU in former war zones is unlikely to produce frank clinical symptoms. The limited data available on DU exposed troops seems to confirm this. The kidney is a target organ for DU yet renal pathology does not seem to exist in this group, despite embedded DU fragments and other types of exposure.

\section{Risk and Exposure Assessment}

An important goal for any toxicologist would be to have a method to determine if particular populations are at risk for some type of adverse health effect from DU exposure. This would require several pieces of information;

1. Knowledge of the exposure level for the group in question;

2. Knowledge of the dose absorbed by the group in question;

3. The route of exposure;

4. Length of exposure;

5. An index or benchmark of exposure likely to produce and adverse effect;

6. An understanding of likely adverse effects to been seen for that group.

Unfortunately, for DU nearly all of this information is lacking. Historically, uranium exposure risk has been assessed in terms of radiation exposure. Most toxicologists have been tempted to treat DU as a chemical exposure risk because of its lower level of radioactivity compared to the native element. However, Durakovic [25] argues that the radiation risk from DU remains substantial, especially if the use of DU produces respirable particles. Durakovic [25] argues that if even a little as $1-2 \%$ of the 300 tons of DU used in the Gulf War were converted to respirable dust (probably a conservative estimate) it would produce three to six million grams of DU dust. Using the figures provided by Durakovic, this would release 1.16 million to 2.32 million $\mathrm{Ci}$ of radiation, a measure that would exceed the New York state safety levels for monthly release of $150 \mathrm{Ci}$ by a factor of 7,733 to 15,467 . These figures seem to suggest that it may not be prudent to completely ignore radiation risks from DU. 
The numbers above may give us pause and force us reconsider the radiation risk to DU but, they bring us no closer to determining who may be exposed, if absorption occurs, if absorption occurs and if they are risk from the dose received. To answer the question concerning exposure studies have been conducted looking at the amount of DU found in soils where DU munitions were used. The bulk of these studies have focused on Kosovo using a variety of methods ranging from examining earthworms and lichen to direct soil measurement. Some studies looked at soil from a general region while others looked at soil relatively close to sites where DU was used. Several of these studies concluded that DU contamination was not present; at least not above background natural uranium levels [26-30]. One study examining soil contamination in Kuwait did not find uranium concentrations greater than the worldwide average [31]. Some recent studies did find DU contamination however; the contamination was either low, or limited in area [32-34] providing no clear indication in either direction concerning the risk from DU.

Using a computer model one study found that there may be significant radiologic and chemical exposure risk from gradual groundwater contamination [35]. In a similar vein soil samples contained enough DU to suggest that DU exposure via dust would present a toxicological hazard over the course of many years [36]. Similarly, by specifically examining the locations where DU shells were used high concentrations of DU particles with diameters less than 5 microns were found [37], a respiratory risk. Finally, a 2003 report found uranium levels in water and soils of selected areas in Afghanistan found levels higher than worldwide concentrations or exceeding WHO standards [38].

The above papers do not provide the scientific community with conclusive evidence, one way or the other, concerning the risk of hazardous DU exposure. The evidence presented above does not answer the question; is DU exposure sufficient to produce body DU levels high enough to produce a health risk either from radiation or chemical hazard?

There are a few papers that directly explore if DU exposure has an impact on the populace. A study in Afghanistan of eight male civilians presenting with a variety of complaints found elevated natural uranium levels, but not elevated DU levels, in the urine of these subjects [39]. Another Afghanistan study found elevated natural, but not depleted, uranium levels in subjects complaining of symptoms similar to Gulf War Illness. A study examined a variety of cellular, chromosomal, and chemical measures in subjects from Serbia and Kosovo. DU levels in urine were measured by alpha and gamma spectrometry. DU contamination was found to be low with a small subset of the study group demonstrating morphologic changes in their blood [14]. A study of non-resident workers in Kosovo indicates that simply being in a country where DU munitions were used is not sufficient to accumulate uranium in the body [40] and longer or more direct DU contact is required for the substance to accumulate. These studies, while suggestive that DU accumulates in the civilian population and produces health effects are confounded by small and non-random samples.
The papers reviewed in this section allow us to draw one conclusion. The conclusion is that with the current data no firm declaration concerning the health risk of DU can be made in either direction. Little is known of its fate in the environment, the number of individuals exposed the length of exposure, or the chemical or radiologic exposure level likely to produce health effects. Larger studies with epidemiologically appropriate sampling and assessment tools need to be conducted.

\section{Current Status of Animals Studies}

The literature on the effects of DU on experimental animals is beginning to grow. In general, animal studies appear to focus on the effects of DU on adult animals, especially central nervous system (CNS) and possible carcinogenic effects, and the effects on developing animals.

Depleted uranium effects on the CNS are now well documented. Evidence that DU is active in the CNS of adult animals includes the accumulation of DU in brain as well as skeleton, muscle, spleen, liver, heart, lung, lymph nodes, testes [41]. That DU is physiologically active in the CNS was demonstrated when implanted DU pellets inhibited spike formation in the hippocampus of rats with no evidence of renal damage [42]. DU accumulates in hippocampus, striatum, and cortex [43], structures important for memory formation and other higher cognitive functions. Rats given high doses of $U$ exhibit tremors [44]. Uranium may compete with calcium at the cellular level, in particular at the neuromuscular endplate [45].

In our laboratory we have demonstrated dose dependent increases in lipid oxidation in the brains of DU exposed mice. Lipid oxidation was correlated with both reactivity and rearing activity in the open-field [46]. There was a general increase in open field activity for both male and female rats that was dependent on length of administration ( 2 weeks or 6 months) [47]. Both linecrossing and rearing were greater, indicating an overall increase of the activity state of the animal. A more intensive study in our laboratory exposed rats to depleted uranium acetate (DU) in doses of 0,75 , or $150 \mathrm{mg} / \mathrm{L}$ in drinking water for a period of 2-weeks or 6-months. After exposure the animals were tested in the open-field maze on a variety of behaviors. Rats exposed for 6months and at the highest dosage demonstrated a variety of behavioral changes in the open-field and oxidation of brain lipids. Rats exposed at lower dosages or for shorter periods demonstrated less significant effects. Lipid oxidation was significantly correlated with behavioral activity [28].

\section{Carcinogenicity of DU}

Evidence of potential carcinogenic effects include suggestions of an increase in cervical carcinomas in Yugoslavia [11, 13] and increases in micronuclei formation in the Bosnia/Herzegovina region [12] and an association of hypoxanthine-guanine phosphoribosyl transferase (HPRT) mutation in some Gulf War veterans [17] as well as other chromosomal aberrations in a German group [49]. DU has been shown to produce 
altered gene expression in vitro [50] as well as producing breakage of DNA strands [51] and carcinogenic mutation of human bronchial tissue [52] and genomic instability of human osteoblasts [53-56]. Genetic changes in mouse macrophages [57] and the production of soft tissue sarcomas in rats [58] has been seen with DU. DU also produces increased urinary mutagenicity using the Ames test in rats [59].

\section{Developmental Effects of DU}

Developing animals are often the most sensitive to the effects of metals. Evidence that DU may produce adverse effects on developing organisms includes evidence that DU reduces litter size, viability, lactation in rodents (native $\mathrm{U},[60]$ ) and may produce maternal toxicity, reduced fetal weight and skeletal malformations (native U) [61]. Similarly, embryolethality and delayed growth was seen in rodents exposed to native U [62]. Other adverse effects include lower maternal weight gain with increased maternal liver weight, reduced fetal weight and body length, renal hypoplasia and up to a $15 \%$ occurrence of skeletal malformations (native $U$, [63]). Gestational day 10 (neural tube formation) appears to be the most vulnerable time for DU exposure [64]. DU does cross the placental barrier and fetal tissue accumulates DU. Work in our laboratory has shown that mice exposed to DU from preconception until 21 days of age demonstrated less line-crossing in an open field maze and took greater time to complete a water maze task [65]. Treated animals also displayed differences in body weight. DU exposed animals displayed differences in behavior on a number of behavioral measures related to reactions to environmental stimuli. DU animals exposed during development also showed greater lipid oxidation in the CNS. These data suggest that chronic exposure of young animals to DU may adversely effect development, brain, and behavior. The affected behavioral spheres include environmental responses, learning, activity, exploration, and emotionality. A separate study also demonstrated that mice exposed to DU during development showed accelerated weight gain, and accelerated development on a number of behavioral indices. We hypothesize that early development of the systems responsible for certain behavioral landmarks occur at the expense of other systems responsible for modulating the response to environmental stimuli, resulting in abnormal behavior as seen in our previous work [65]. Uranium exposed mouse pups also had larger body weights at time of sacrifice but smaller brain weights (as a percentage of body weight) [66].

\section{Theoretical Consequences of Human DU Exposure}

If research on DU is to proceed, presumably by using an epidemiologic approach, it would be useful to have some insight concerning the endpoints of low level DU toxicity. Animal studies do provide us with some clues. The current animal literature would seem to indicate that DU is likely to have subtle CNS effects. This would most likely be manifested in subtle cognitive effects; math and verbal comprehension skills are often considered to be very vulnerable to a variety of insults. Subtle behavioral effects seen in animals are likely to produce a parallel effect in humans, possibly manifesting in a form of attention deficit hyperactivity behaviors. These types of effects are difficult to measure even in countries with well developed educational and health systems. In regions of the world where these systems are not as well developed research along this line will be very challenging.

The potential general health effects and carcinogenicity are even less well defined for low dose DU exposure than they are for its' CNS effects. Increased animal research in this area would probably be an efficient approach to arrive at a well-defined model of human effects. Epidemiologic studies of human effects could then proceed with greater efficiency.

\section{What We Do Not Know/What Other Metals Might Teach Us.}

The United States military has suggested that DU is no more toxic than lead. This claim is yet to be substantiated empirically and is not likely to alleviate concern over the toxicity of DU given the welldocumented toxicity of lead. The potential toxic effects of DU due to environmental exposure are likely to prove difficult to study. In part, this is due to the lack of experimental data in animals at the low levels likely to mimic human exposure. Further complicating this matter is that the amount of DU currently in the environment, while important, is not enormous when compared to other contaminants. The continued use of DU is likely to change this circumstance. Common to the study of other environmental contaminants DU exposed groups are also under the influence of economic status, nutritional factors, genetic variables and other confounding variables likely to cloud the potential effects of DU.

It is possible to optimize the data gathering and research potential of studies on DU by taking into account what we know of the toxicities of other metals. The primary route of toxicity for DU is likely to be chemical rather than radiologic and metals with similar chemistry may foreshadow the effects of DU. Such a metal should be heavy, have a similar route of exposure, similar distribution and physiologic activity and similar chemical fates in the human body. Lead is such a metal. It is a heavy metal, largely divalent after systemic absorption $\left(\mathrm{Pb}^{2+} / \mathrm{UO}_{2}\right)^{2+}$, dust is the most common manner of exposure [67], is largely deposited in bone [68], and has biological and behavioral effects fairly similar to what has so far been demonstrated for DU [69, 70]. It would seem reasonable to take a cue from what we know of lead toxicity and look for similar effects in DU exposed populations, allowing researchers to maximize their research efforts.

The biochemical effects of uranium are not nearly as well studied as those for lead, which has an extensive literature, especially for lower dose exposure [71]. Some literature does exist indicating that uranium has some biochemical effects similar to lead. Lead and uranium both induce heat shock protein formation [72, 73], the activation of protein-kinase-C [74] and increases in tumor necrosis factor $[75,76]$.

However, there are differences between lead and uranium. In blood, $90 \%$ of lead is associated with either 
hemoglobin or the membranous components of red blood cells and the bulk of lead body burden is associated with the skeleton. Uranium in blood is about $40 \%$ plasma bound and the remainder is found as the soluble uranyl ion. Inhaled lead and uranium dust (as the oxides) both appear to have pulmonary half-lives of about 4-5 years. However, the skeletal half-life of lead is about 20 years but uranium has a skeletal half-life of less than 1.5 years, making the long-term kinetics of the two metals substantially different $[71,77]$. Despite these differences there appears to be enough "face validity" to suggest that lead may be a useful model to anticipate the effects of uranium exposure until the time that the scientific literature on DU has matured.

Provided that DU is similar in its' biological activity to lead we are likely to see effects that are subtle, but pervasive, and most likely to impact children. Lead is well documented to have a negative impact on intellectual function at very low blood concentrations [78, 79]. These effects are likely to be seen only using large sample sizes and fairly sophisticated designs and tools for measurement.

\section{References}

1. Salbu, B.; Janssens, K.; Lind O. C.; Proost, K.; Danesi, P. R.: Oxidation states of uranium in DU particles from Kosovo. J. Environ. Radioact. 2003, 64, 167-173.

2. Durakovic, A.; Horan, P.; Dietz, L. A.; Zimmerman, I.: Estimate of the time zero lung burden of depleted uranium in Persian Gulf War veterans by the 24hour urinary excretion and exponential decay analysis. Mil. Med. 2003, 168, 600-605.

3. Giannardi, C.; Dominici, D.: Military use of depleted uranium: assessment of prolonged population exposure. J. Environ. Radioact. 2003, 64, 227-236.

4. Ribera, R.; Labrot, F.; Tisnerat, G.; Narbonnet, J-F.: Uranium in the environment: occurrence, transfer and biological effects. Rev. Environ. Contam. Toxicol., 1996, 146, 53-89.

5. Mould, R. F.: Depleted uranium and radiationinduced lung cancer and leukaemia. $B r . J$. Radiology 2001, 74, 677-683.

6. WHO/SDE/ PHE/01.1. Depleted uranium: sources, exposure and health effects. WHO: Geneva: Department of Protection of the Human Environment, 2001. 1997, 12, 964-969.

7. Agency for Toxic Substances and Disease Registry. Toxicological profile for uranium. Washington, DC: US Public Health Service, 1999.

8. Environmental Exposure Report (http://www.deploymentlink.osd.mil/du_library/du_i i/index.htm).

9. Dept of Defense. News Transcript. http://www.defenselink.mil/transcripts/2003/t03142 003_t314depu.html.

10. Rolling Stone. Is the Pentagon Giving Our Soldiers Cancer? 2003. Oct. $2^{\text {nd }}$.Vol. 293, pg 74-80.

11. Papathanasiou, K.; Gianoulis, C.; Tolikas, A.; Dovas, D.; Koutsos, J.; Fragkedakis, N.; Papathanasiou, N.: Effect of depleted uranium weapons used in the Balkan war on the incidence of cervical intraepithelial neoplasia (CIN) and invasive cancer of the cervix in Greece. Clin. Exp. Obstet. Gynecol. 2005, 32, 58-60.

12. Ibrulj, S.; Krunic-Haveric, A.; Haveric, S.; Pojskic, N.; Hadziselimovic. R.: Micronuclei occurrence in population exposed to depleted uranium and control human group in correlation with sex, age and smoking habit. Med. Arch. 2004, 58, 335-8.

13. Obralic, N.; Gavrankapetanovic, F.; Dizdarevic, Z.; Duric, O.; Sisic, F.; Selak, I.; Balta, S.; Nakas, B.: The number of malignant neoplasm in Sarajevo region during the period 1998-2002. Med. Arch. 2004, 58, 275-8.

14. Milacic, S.; Petrovic, D.; Jovicic, D.; Kovacevic, R.; Simic, J.: Examination of the health status of populations from depleted-uranium-contaminated regions. Environ Res. 2004, 95, 2-10.

15. Labar, B.; Rudan, I.; Ivankovic, D.; Biloglav, Z.; Mrsic, M.; Strnad, M.; Fucic, A.; Znaor, A.; Bradic, T.; Campbell, H.: Haematological malignancies in childhood in Croatia: investigating the theories of depleted uranium, chemical plant damage and 'population mixing'. Eur. J. Epidemiol. 2004, 19, 55-60.

16. Gustavsson, P.; Talback, M.; Lundin, A.; Lagercrantz, B.; Gyllestad, P. E.; Fornell, L. Incidence of cancer among Swedish military and civil personnel involved in UN missions in the Balkans 1989-99. Occup. Environ. Med. 2004, 61, 171-173.

17. McDiarmid, M. A.; Engelhardt, S.; Oliver, M.; Gucer, P.; Wilson, P. D.; Kane, R.; Kabat, M.; Kaup, B.; Anderson, L.; Hoover, D.; Brown, L.; Handwerger, B.; Albertini, R. J.; Jacobson-Kram, D.; Thorne, C. D.; Squibb, K. S.: Health effects of depleted uranium on exposed Gulf War veterans: a 10-year follow-up. J. Toxicol. Environ. Health A. 2004, 67, 277-96.

18. Macfarlane, G. J.; Biggs, A. M.; Maconochie, N.; Hotopf, M.; Doyle, P.; Lunt, M.: Incidence of cancer among UK Gulf war veterans: cohort study. BMJ. 2003, 327, 1373.

19. Sumanovic-Glamuzina, D.; Saraga-Karacic, V.; Roncevic, Z.; Milanov, A.; Bozic, T.; Boranic, M.: Incidence of major congenital malformations in a region of Bosnia and Herzegovina allegedly polluted with depleted uranium. Croat. Med. J. 2003, 44, 579-84.

20. Shawky, S.: Causes of death in the Eastern Mediterranean Region during the years 1998-2000. Saudi Med. J. 2003, 24, 380-7.

21. http://www.nato.int/du/

22. McDiarmid, M. A.; Engelhardt, S. M.; Oliver, M.: Urinary uranium concentrations in an enlarged Gulf War veteran cohort. Health Physics. 2001, 80, 270-273.

23. McDiarmid, M. A.; Keogh, J. P.; Hooper, F. J.; McPhaul, K.; Squibb, K.; Kane, R.; DiPino, R.; Kabat, M.; Kaup, B.; Anderson, L.; Hoover, D.; Brown, L.; Hamilton, M.; Jacobson-Kram, D.; Burrows, B.; Walsh, M.: Health effects of depleted uranium on exposed Gulf War veterans. Environ. Res. 2000, 82, 168-180. 
24. Schroder, H.; Heimers, A.; Frentzel-Beyme, R.; Schott, A.; Hoffman, W.: Chromosome aberration analysis in peripheral lymphocytes of Gulf War and Balkans War veterans. Radiat. Prot. Dosimetry, 2003, 103, 211-219.

25. Durakovic, A.: Medical effects of internal contamination with uranium. Croatian Med. J. 1999, 40, 49-66.

26. DiLella, L.A.; Nannoni, F.; Protano, G.; Riccobono, F.: Uranium content and (235)U/(238)U atom ratios in soil and earthworms in western Kosovo after the 1999 war. Sci. Total Environ. 2005, 337, 109-118.

27. DiLella, L.A.; Frati, L.; Loppi, S.; Protano, G.; Riccobono, F.: Environmental distribution of uranium and other trace elements at selected Kosovo sites. Chemosphere, 2004, 56, 861-865.

28. Esposito, M.; Polic, P.; Bartolomei, P.; Benzi, V.; Martellini, V.; Cvetkovic, O.; Damjanova, V.; Simic, M.; Zunic, Z.; Zivancevic, B.; Simic, S.; Jovanovic, V.: Survey of natural and anthropogenic radioactivity in environmental samples from Yugoslavia. J. Environ. Radioact. 2002, 61, 271-282.

29. Loppi, S.; Riccobono, F.; Zhang, Z. H.; Savic, S.; Ivanov, D.; Pirintsos, S. A.: Lichens as biomonitors of uranium in the Balkan area. Environ. Pollut. 2003, 125, 277-280.

30. Uyttenhove, J.; Lemmens, M.; Zizi, M.: Depleted uranium in Kosovo: results of a survey by gamma spectrometry on soil samples. Health Phys. 2002, 83, 543-548.

31. Bem, H.; Bou-Rabee, F.: Environmental and health consequences of depleted uranium use in the 1991 Gulf War. Environ. Int. 2004, 30, 123-134.

32. Papastefanou, C.: Depleted uranium in military conflicts and the impact on the environment. Health Phys. 2002, 83, 280-282.

33. Sansone, U.; Stellato, L.; Jia, G.; Rosamilia, S.; Gaudino, S.; Barbizzi, S.; Belli, M.: Levels of depleted uranium in Kosovo soils. Radiat. Prot. Dosimetry. 2001, 97, 317-320.

34. Sansone, U.; Danesi, .R.; Barbizzi, S.; Belli, M.; Campbell, M.; Gaudino, S.; Jia, G.; Ocone, R.; Pati, A.; Rosamilia, S.; Stellato, L.: Radioecological survey at selected sites hit by depleted uranium ammunitions during the 1999 Kosovo conflict. Sci. Total Environ. 2001, 281, 23-35.

35. Durante, M.; Pugliese, M.: Depleted uranium residual radiological risk assessment for Kosovo sites. J. Environ. Radioact. 2003, 64, 237-245.

36. Giannardi, .; Dominici, D. Military use of depleted uranium: assessment of prolonged population exposure. J. Environ. Radioact. 2003, 64, 227-236.

37. Danesi, P.R.; Markowicz, A.; Chinea-Cano, E.; Burkart, W.; Salbu, B.; Donohue, D.; Ruedenauer, F.; Hedberg, M.; Vogt, S.; Zahradnik, P.; Ciurapinski, A.: Depleted uranium particles in selected Kosovo samples. J. Environ. Radioact. 2003, 64, 143-154.

38. Durakovic, A.: Undiagnosed illnesses and radioactive warfare. Croat. Med. J. 2003, 44, 520-532.

39. Durakovic, A. The quantitative analysis of uranium isotopes in the urine of the civilian population of eastern Afghanistan after operation enduring freedom. Mil. Med. 2005, 170, 277-284.

40. Meddings, D.R.; Haldimann, M. Depleted uranium in Kosovo: an assessment of potential exposure for aid workers. Health Phys. 2002, 82, 467-472.

41. Pellmar, T. C.; Fuciarelli, A. F.; Ejnik, J. W.; Hamilton, M.; Hogan. J.; Strocko. S.; Emond. C.; Mottaz, H. M.; Landaur, M. R. Distribution of uranium in rats implanted with depleted uranium pellets. Toxicological Sciences. 1999, 49, 29-39.

42. Pellmar, T. C.; Keyser, D. O.; Emery, C.; Hogan, J. B.: Electrophysiological changes in hippocampal slices isolated from rats embedded with depleted uranium fragments. Neurotoxicology, 1999, 20, 785-792.

43. Barber, D. S.; Ehrich, M. F.; Jortner, B. S.: The effect of stress on the temporal and regional distribution of uranium in rat brain after acute uranyl acetate exposure. J. Toxicol. Environ. Health A. 2005, 68, 99-111.

44. Domingo, J. L.; Llobet, J. M.; Tomas, J. M.; Corbella, J. Acute toxicity of uranium in rats and mice. Bull. Environ. Contam. Toxicol. 1987, 39, 168-174.

45. Lin, R. H.; Fu, W. M.; Lin-Shiau, S. Y. Presynaptic action of uranyl nitrate on the phrenic nervediaphragm preparation of the mouse. Neuropharmacology. 1988, 27, 857-863.

46. Briner, W.; Davis, D. Lipid oxidation and behavior are correlated in depleted uranium exposed mice. In: Metal Ions in Biology and Medicine. Khassanova, L.; Collery, Ph.; Maymard, I.; Khassanova, Z.; Etienne JC. (eds.), John Libby Eurotext, Paris, 2002, Vol. 7, pp. 59-63.

47. Briner, W. Altered open-field performance in depleted uranium exposed rats, In: Metal Ions in Biology and Medicine. Khassanova, L.; Collery, Ph.; Maymard, I.; Khassanova, Z.; Etienne JC. (eds.), John Libby Eurotext, Paris, 2002, Vol. 7, pp. 342-345.

48. Briner, W.; Murray, J.: Effects of short-term and long-term depleted uranium exposure on open-field behavior and brain lipid oxidation in rats. Neuotoxicology and Teratology, 2005, 27, 135-144.

49. Schroder, H.; Heimers, A.; Frentzel-Beyme, R.; Schott, A.; Hoffmann, W.: Chromosome aberration analysis in peripheral lymphocytes of Gulf War and Balkans War veterans. Radiat. Prot. Dosimetry. 2003, 103, 211-219.

50. Miller, A. C.; Brooks, K.; Smith, J.; Page, N.: Effect of the militarily-relevant heavy metals, depleted uranium and heavy metal tungsten-alloy on gene expression in human liver carcinoma cells (HepG2). Mol. Cell Biochem. 2004, 255, 247-256.

51. Yazzie, M.; Gamble, S. L.; Civitello, E. R.; Stearns, D. M.: Uranyl acetate causes DNA single strand breaks in vitro in the presence of ascorbate (vitamin C). Chem. Res. Toxicol. 2003, 16, 524-530.

52. Yang, Z. H.; Fan, B. X.; Lu, Y.; Cao, Z. S.; Yu, S.; Fan, F. Y.; Zhu, M. X.: [Malignant transformation of human bronchial epithelial cell (BEAS-2B) induced by depleted uranium]. Ai Zheng 2002, 21, 944-948. 
53. Miller, A. C.; Brooks, K.; Stewart, M.; Anderson, B.; Shi, L.; McClain, D.; Page, N.: Genomic instability in human osteoblast cells after exposure to depleted uranium: delayed lethality and micronuclei formation. J. Environ. Radioact. 2003, 64, 247-259.

54. Miller, A. C.; Xu, J.; Stewart, M.; Brooks, K.; Hodge, S.; Shi, L.; Page, N.; McClain, D.: Observation of radiation-specific damage in human cells exposed to depleted uranium: dicentric frequency and neoplastic transformation as endpoints. Radiat. Prot. Dosimetry 2002, 99, 275-278.

55. Miller, A. C.; Xu, J.; Stewart, M.; McClain, D.: Suppression of depleted uranium-induced neoplastic transformation of human cells by the phenyl fatty acid, phenyl acetate: chemoprevention by targeting the p21RAS protein pathway. Radiat. Res. 2001, 155, 163-170.

56. Miller, A. C.; Blakely, W. F.; Livengood, D.; Whittaker, T.; Xu, J.; Ejnik, J. W.; Hamilton, M. M.; Parlette, E.; John. T. S.; Gerstenberg, H. M.; Hsu, H.: Transformation of human osteoblast cells to the tumorigenic phenotype by depleted uranium-uranyl chloride. Environ. Health Perspect. 1998, 106, 465-471.

57. Kalinich, J. F.; Ramakrishnan, N.; Villa, V.; McClain, D. E. Depleted uranium-uranyl chloride induces apoptosis in mouse $\mathrm{J} 774$ macrophages. Toxicology. 2002, 179, 105-114.

58. Hahn, F. F.; Guilmette, R. A.; Hoover, M. D. Implanted depleted uranium fragments cause soft tissue sarcomas in the muscles of rats. Environ. Health Perspect. 2002, 110, 51-59.

59. Miller, A. C.; Fuciarelli, A. F.; Jackson, W. E.; Ejnik, E. J.; Emond, C.; Strocko, S.; Hogan, J.; Page, N.; Pellmar, T. Urinary and serum mutagenicity studies with rats implanted with depleted uranium or tantalum pellets. Mutagenesis. 1998, 13, 643-648.

60. Domingo, J. L.; Ortega, A.; Paternian, J. L.; Corbella, J.: Evaluation of the perinatal and postnatal effects of uranium in mice upon oral administration. Arch. Env. Health. 1989, 44, 395-398.

61. Bosque, M. A.; Domingo, J. L.; Llobet, J. M.; Corbella, J. Embryotoxicity and teratogenicity of uranium in mice following subcutaneous administration of uranyl acetate. Biol Trace Elem Res, 1993, 36, 109-118.

62. Paternain, J. L.; Domingo, J. L.; Ortega, A.; Llobet, J. M.: The effects of uranium on reproduction, gestation, and postnatal survival in mice. Ecotoxi Environ. Safety. 1989, 17, 291-296.

63. Domingo, J. L.; Ortega, A.; Paternain, J. L.; Corbella, J.: Evaluation of the perinatal and postnatal effects of uranium in mice upon oral administration. Archv. Environ. Health, 1989, 44, 395-398.

64. Domingo, J. L.: Reproductive and developmental toxicity of natural and depleted uranium: a review. Reprod. Toxicol., 2001, 15, 603-609.

65. Briner, W.; Byrd, K.: Effects of depleted uranium on development of the mouse. In: Metal Ions in Biology and Medicine. Centeno, J.; Collery, Ph.; Vemet, G.; Finkelman, R. B.; Gibb, H.; Etienne, J. C. (eds), John Libby Eurotext: Paris, 2000, Vol. 6, pp. 459-461.
66. Briner, W.; Abboud, B.: Behavior of juvenile mice chronically exposed to depleted uranium In: Metal Ions in Biology and Medicine. Khassanova, L.; Collery, Ph.; Maymard, I.; Khassanova, Z.; Etienne JC. (eds.), John Libby Eurotext, Paris, 2002, Vol. 7, pp. 353-356.

67. Mielke, H. W.: Lead in the inner cities. American Scientist. 1999, 87, 62-73.

68. Goyer, R. A. Toxic effects of metals. In: Casarett and Doull's Toxicology, The Basic Science of Poisons $4^{\text {th }}$. Amdur, M. O.; Doull, J.; Klassen, C. D. (eds). McGraw-Hill: NY. 1991, pp. 671-672.

69. Jet, D. A.; Guilarte, T. R.: Developmental lead exposure alters N-methyl-D-aspartate and muscarinic cholinergic receptors in the rat hippocampus: an autoradiographic study. Neurotoxicology, 1995, 16, 7-18.

70. Needleman, H. L.; McFarlnad, C.; Ness, R. B.; Fienberg, S. E.; Tobin, M. J.: Bone lead levels in adjudicated delinquents. A case control study. Neurotoxicology and Teratology, 2002, 24, 711-717.

71. Goyer, R.A. Toxic effect of metals. In: Casarett and Doull's Toxicology. The Basic Science of Poisons, $4^{\text {th }}$. Amdur, M.O.; Doull, J.; Klaassen, C.D. (eds) McGraw Hill, 1991, pp. 623-680.

72. Mizuno, S.; Fujita, K.; Furuy, R.; Hishid, A.; Ito, H.; Tashim, Y.; Kumagai, H.: Association of HSP73 with acquired resistance to uranyl acetate-induced acute renal failure. Toxicology, 1997, 117, 183-191.

73. Tolson, J. K.; Roberts, S. M.; Jortner, B.; Pomeroy, M.; Barber, D. S.: Heat shock proteins and acquired resistance to uranium nephrotoxicity. Toxicology, 2005, 206, 59-57.

74. Gazin, V.; Kerdine, S.; Grillon, G.; Pallardy, M.; Raoul, H.: Uranium induces TNF alpha secretion and MAPK activation in a rat alveolar macrophage cell line. Toxicol. Appl. Pharmacol., 2004, 194, 49-59.

75. Popp, W.; Plappert, U.; Muller, W. U.; Rehn, B.; Schneider, J.; Braun, A.; Bauer, P. C.; Vahrenholz, C.; Presek, P.; Brauksiepe, A.; Enderle, G.; Wust, T.; Bruch, J.; Fliedner, T. M.; Konietzko, N.; Streffer, C.; Woitowitz, H. J.; Norpoth, K. Biomarkers of genetic damage and inflammation in blood and bronchoalveolar lavage fluid among former German uranium miners: a pilot study. Radiat. Environ. Biophys., 2000, 39, 275-282.

76. Kojima, M.; Sekika, K.; Nemoto, K.; Degawa, M.: Tumor necrosis factor-alpha-independent down regulation of hepatic cholesterol 7alph-hydroxylase gene in mice treated with lead nitrate. Toxicol. Sci. 2005, 87, 537-542.

77. Brugge, D.; deLemos, J. L.; Oldmixon, B.: Exposure pathways and health effects associated with chemical and radiological toxicity of natural uranium: a review. Rev. Environ. Health, 2005, 20, 177-193.

78. Bellinger, D. C.; Needleman, H. L.: Lead and the relationship between maternal and child intelligence. Journal of Pediatrics, 1983, 102, 523-527.

79. CDC. Managing Elevated Blood Lead Levels Among Young Children: Recommendations from the Advisory Committee on Childhood Lead Poisoning Prevention. CDC: Atlanta, 2002. 